\title{
FRACTURED FEMORAL SHAFT THROUGH AN OSTEOLYTIC LESION RESULTING FROM THE REACTION TO A PROSTHESIS
}

\author{
A CASE REPORT
}

\author{
UGO PAZZAGLIA, PAUL D. BYERS
}

From the Institute of Orthopaedics, Stanmore

\begin{abstract}
This paper reports a singular case of pathological fracture through a large osteolytic lesion of the midfemur consequent on reaction to a hip prosthesis. Not only metal particles but also polyethylene fibres were found at this site, some $15 \mathrm{~cm}$ from the prosthesis. The case sheds an interesting light on the reaction to prostheses.
\end{abstract}

Fracture of the femoral shaft in patients with a total hip arthroplasty fixed with acrylic cement is rare, and is seldom found among the complications reported in the literature. Neither Charnley, Follacci and Hammond (1968) nor Charnley and Cupic (1973) included such a case in their patients followed up for 4 and 9-10 years respectively. This contrasts with the general experience of uncemented endoprostheses.

Cupic (1979) reported two femoral diaphysial fractures below the apex of the stem in a series of 405 arthroplasties with an average follow-up of 11.5 years. Luck, Brannon and Luck (1972) reported one femoral fracture $5 \mathrm{~cm}$ proximal to the apex of the stem. McElfresh and Coventry (1974) reported seven femoral fractures in a series of 5400 total hip arthroplasties; they occurred from 4 to 20 months after the operation. Two fractures just below the apex of the femoral stem were reported by Nolan et al. (1975). Scott et al. (1975) reported seven postoperative fractures, two in the distal end of the femur and five in the proximal femoral shaft. In four of these the diaphysial cortical bone was weakened by a cortical defect produced when removing the cement of former procedures. In these reports the time between the prosthetic implant and the fracture ranged from 1 month to 8 years. Fractures occurred either spontaneously or after a fall. All authors referred to weakening of the cortical bone by previous surgical procedures or by osteoporosis.

In reviewing the literature on cemented hip prostheses we have found no instance of a postoperative femoral fracture related to bone resorption in association with foreign-body granulation tissue, although such bone resorption is well recorded. Charnley (1975) reported

U. Pazzaglia, MD, Specialist in Orthopaedics and Traumatology Clinica Ortopedica dell Universita di Pavia, Pavia, Italy.

P. D. Byers, FRCPath, Head

Department of Morbid Anatomy, Institute of Orthopaedics, Brockley Hill, Stanmore, Middlesex HA7 4LP, England.

Requests for reprints should be sent to Dr P. D. Byers.

(C) 1984 British Editorial Society of Bone and Joint Surgery $0301-620 \times / 84 / 3068 \$ 2.00$ circumscribed bone resorption around cement; at surgical revision he observed caseous material similar to that found in erosions around the calcar femoris, but no birefringent particles of polyethylene were seen. Harris et al. (1976), in four total hip arthroplasties, found

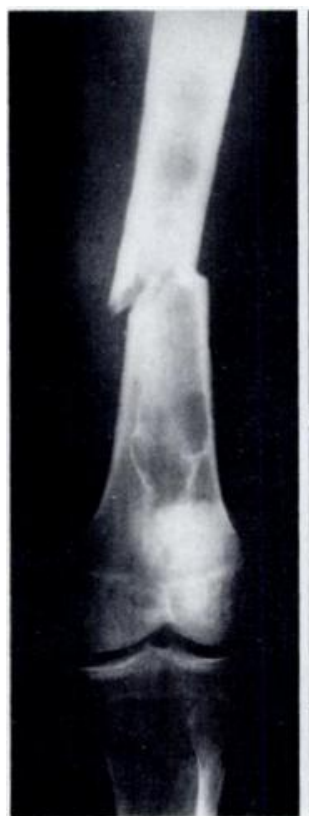

Fig. 1

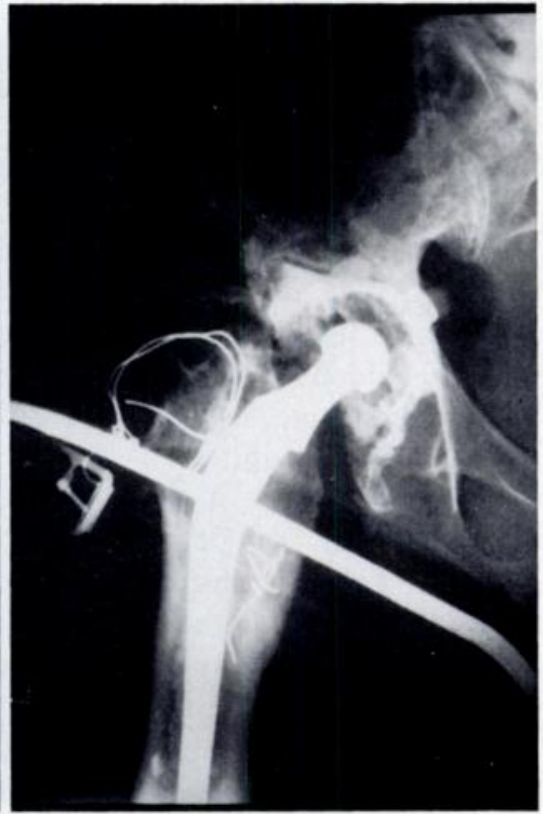

Fig. 2
Figure 1-Pathological fracture through a large osteolytic lesion of the femur, which extends well into the distal metaphysis. Figure 2 - There is a linear loss of bone adjacent to the stem of the prosthesis.

foreign-body granulation tissue around the cement at the site of bone resorption in the femoral diaphysis. Willert (1973) and Willert and Semlitsch (1976) described foreign-body granulation tissue and bone resorption around the cement in the proximal end of the femur after the accumulation of wear particles.

We report a case in which, after prosthetic replacement of the hip, diffusion of particulate matter gave rise to a large cavity in the distal diaphysial and metaphysial region and to a pathological fracture. 




Fig. 3

Granulation tissue with round cells (haematoxylin and eosin, $\times 50$ ).

\section{CASE REPORT}

A man aged 80 years developed a fracture of the femoral diaphysis through an extensive osteolytic lesion involving both the diaphysis and the distal metaphysis (Fig. 1). Nine years earlier a Charnley hip arthroplasty had been performed on the same side for osteoarthritis. Recently there had been loosening of the femoral stem with development of a gap, $3 \mathrm{~mm}$ or more, between bone and cement (Fig. 2). A biopsy was taken from the fracture site.

Methods. The biopsy specimens were fixed in neutral formaldehyde. Both soft and calcified tissues were available; the latter were decalcified in EDTA. They were embedded in paraffin and the sections, stained with haematoxylin and eosin, were studied in a bright field and in polarised light.

Observations. Most of the soft tissue was mature and fibrous, containing foci of particulate matter. It also included a blood clot and amorphous, eosinophilic material with the character of fibrin; both of these were undergoing organisation (Fig. 3). The features associated with the particles were as follows.

1. Large holes surrounded by giant cells or a fibrous capsule. Inside some of the holes were very small black particles, not birefringent (Fig. 4). These were the site of methylmethacrylate globules as originally described by Charosky, Bullough and Wilson (1973) and Mirra et al. (1976). The acrylic cement is removed by solvents used in the embedding procedures leaving holes, empty except for the small black barium particles which have been mixed with the methacrylate.

2. Large birefringent polyethylene fibres surrounded by giant cells or by a fibrous capsule (Fig. 4).

3. Small black particles, generally less than $1 \mu \mathrm{m}$, lying inside the cytoplasm of spindle cells; these were not very numerous, and were scattered throughout all the granulation tissue (Fig. 5). Rounded phagocytic histiocytes were not in evidence.

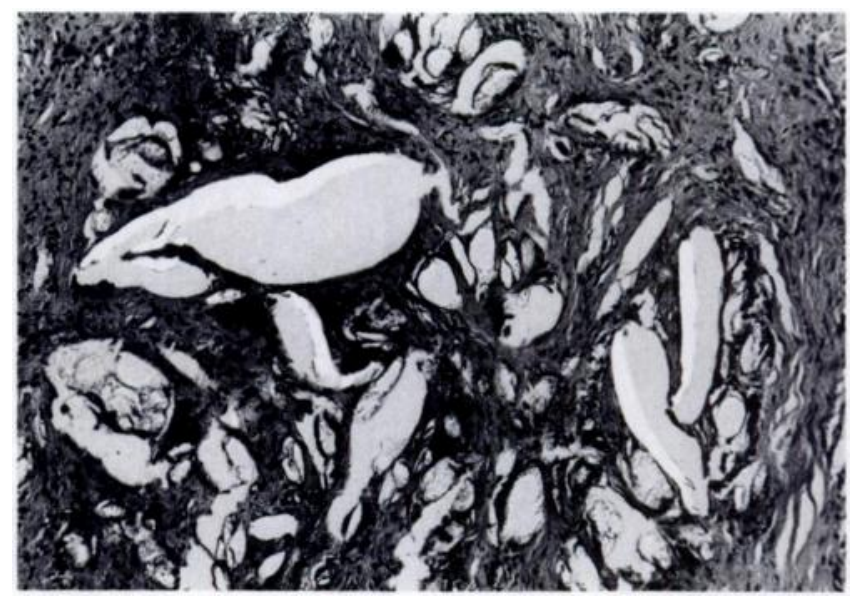

Fig. 4

Reactive tissue containing globules of methylmethacrylate, most of which has dissolved: the barium incorporated in the methacrylate is not readily apparent in photomicrographs. Lanceolate polyethylene fibres which are birefringent appear as white strands attached to one wall of the space (haematoxylin and eosin, $\times 50$; partially polarised light).

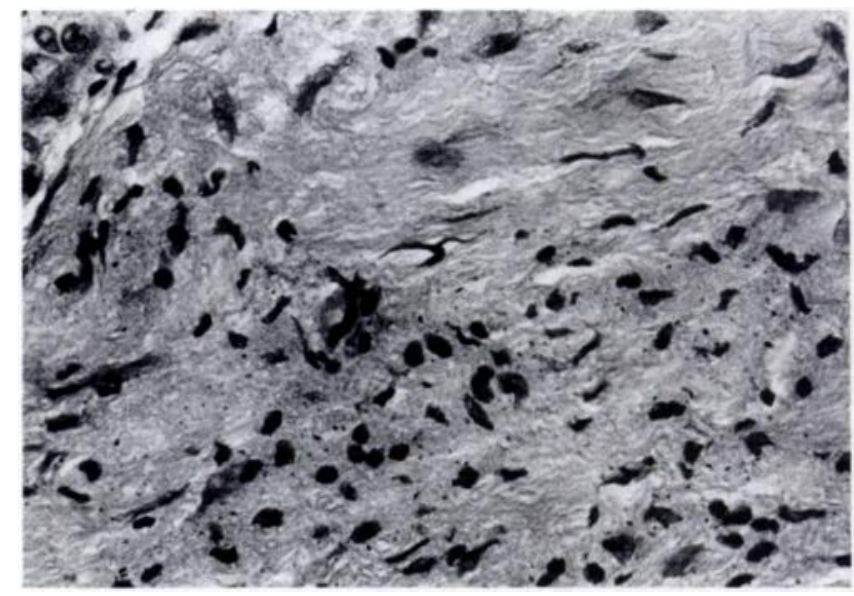

Fig. 5

Small black metallic particles within the fibrous tissue (haematoxylin and eosin, $\times 200)$.

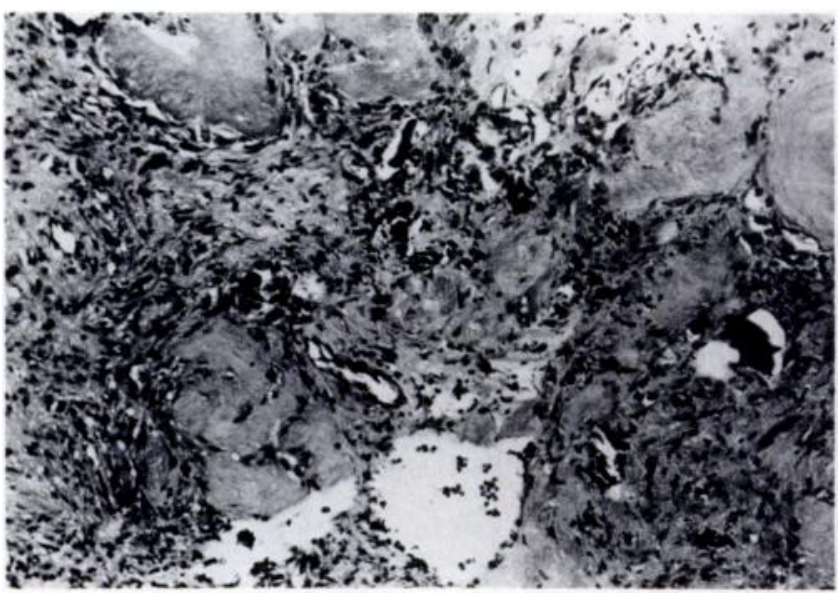

Fig. 6

Fragments of bone incorporated in the reactive tissue (haematoxylin and eosin, $\times 50$ ). 
4. Small necrotic bone particles were also observed, scattered throughout the granulation tissue (Fig. 6).

The bony tissues included in the histological material consisted of mature lamellar cortical bone with frequent resorption lacunae, many of which contained osteoclasts (Fig. 7).

\section{DISCUSSION}

Extension of the reaction to a hip prosthesis to a point well beyond the prosthesis (in this case about $15 \mathrm{~cm}$ distal to the tip of the stem) is quite exceptional and so far unreported in the literature. The presence of methylmethacrylate particles and necrotic bone fragments in this distant tissue is not difficult to explain in a loosened prosthesis, because they may be formed by wear between the bone and the cement envelope around the stem. Not only gravity favours their diffusion downwards, but also the growing granulation tissue, which is contained in a rigid tube (the diaphysial channel) and is closed at the top by the prosthesis.

Metal particles formed by mechanical or biochemical means may, with a loose prosthesis, be found between the stem and the cement. These particles can then migrate down the femoral shaft by passing through a fracture in the cement, or by surmounting it at the neck of the prosthesis. The small size of the particles account for their dispersion far from the site of production, to which they are carried in lymphatics or by cellular migration or both. Quite unexpected are polyethylene fibres in this distant location. They are products of the acetabular cup; their size is large (more than $200 \mu \mathrm{m}$ ), so they are engulfed by giant cells or encapsulated by fibrous tissue. Their transport cannot be accounted for by the mechanism used for metal particles. Necessarily they must have reached the lower femoral region by passing between the cement and the cortical bone, and an indispensable condition must be a large gap there. One can speculate



Fig. 7

Viable bone fragments undergoing resorption: there is not a comparable osteoblastic activity (haematoxylin and eosin. $\times 50)$.

that plunger movements of the loosened stem favour the migration of these large particles. Whatever the transport mechanism, bone resorption must have occurred in the presence of this foreign material and its associated reactive tissue. The resulting weakening of the bone accounts for the pathological fracture.

The situation must be fundamentally similar to that pertaining in loosening: the arguments for and against a direct action by enzymes from the reactive tissue or by induced osteoclastic resorption are the same. Whatever the means, the interest of this case lies in the extension of the reaction to a great distance, far from any mechanical factor directly attributable to the prosthesis. The case invites two hypotheses. One hypothesis is that the extension of the reaction to a prosthesis is normally opposed or contained, and that in our case this factor failed. Alternatively, it can be supposed that a singular combination of factors in the present case led to the striking extension of reactive tissue. The significance of the case depends upon which hypothesis is favoured.

The contribution of Mr J. E. Woodyard. FRCS. Consultant Orthopaedic Surgeon, Staffordshire General Infirmary, to the publication of this case is gratefully acknowledged: and of Dr S. A. Bari who requested a second opinion on the biopsy.

\section{REFERENCES}

Charnley J. Fracture of femoral prostheses in total hip replacement: a clinical study. Clin Orthop 1975;111:105-20.

Charnley J, Follacci FM, Hammond BT. The long-term reaction of bone to self-curing acrylic cement. J Bone Joint Surg [Br] 1968:50-B:822-9.

Charnley J, Cupic Z. The nine and ten year results of the low-friction arthroplasty of the hip. Clin Orthop 1973;95:9-25.

Charosky CB, Bullough PG, Wilson PD. Total hip replacement failures: a histological evaluation. J Bone Joint Surg / Am/ 1973:55-A : 49-58.

Cupic Z. Long-term follow-up of Charnley arthroplasty of the hip. Clin Orthop 1979;141:28-43.

Harris WH, Schiller AL, Scholler JM, Freiberg RA, Scott R. Extensive localised bone resorption in the femur following total hip replacement. $J$ Bone Joint Surg [Am] 1976:58-A:612-8.

Luck JV, Brannon EW, Luck JV Jr. Total hip replacement arthroplasties: causes, orthopaedic management and prevention of selected problems J Bone Joint Surg [Am] 1972:54-A : 1569-71.

Mirra JE, Amstutz HC, Matos M, Gold R. The pathology of the joint tissues and its clinical relevance in prosthesis failure. Clin Orthop 1976:117:221-40.

McElfresh EC, Coventry MB. Femoral and pelvic fractures after total hip arthroplasty. J Bone Joint Surg [Am] 1974;56-A :483-92.

Nolan DR, Fitzgerald RG, Beckenbaugh RD, Coventry MB. Complications of total hip arthroplasty treated by reoperation. $J$ Bone Joint Surg [ Am] 1975:57-A:977-81.

Scott RD, Turner RH, Leitzes SM, Aufranc OE. Femoral fractures in conjunction with total hip replacement. J Bone Joint Surg [Am] 1975; 57-A:494-501

Willert H-G. Tissue reactions around joint implants and bone cement. In: Chapchal G, ed. Arthroplasty of the hip. Stuttgart : G. Thieme Publishers. 1973:11-21.

Willert HG, Semlitsch M. Tissue reactions to plastic and metallic wear, products of joint endoprostheses. In : Gschwend N, Debrunner HV, eds Total hip prosthesis. Bern, Stuttgart and Vienna: H. Huber Publishers, 1976: 205-39. 